\title{
Carbon Sequestration Potential in Aboveground Biomass of Hybrid Eucalyptus Plantation Forest
}

\author{
Siti Latifah*, Nurdin Sulistiyono \\ Forestry Study Program, Faculty of Agriculture, \\ University of North Sumatera, Jalan Tri Darma Ujung No. 1 \\ Campus USU, Medan 20155, Indonesia
}

Received November 21, 2011/Accepted March 14, 2013

\begin{abstract}
Forests are a significant part of the global carbon cycle. Forests sequester carbon by conducting photosynthesis, which is the process of converting light energy to chemical energy and storing it in the chemical bonds of sugar. Carbon sequestration through forestry has the potential to play a significant role in ameliorating global environmental problems such as atmospheric accumulation of GHG's and climate change. The present investigation was carried out to determine carbon sequestration potential of hybrid Eucalyptus. This study was conducted primarily to develop a prediction model of carbon storage capacity for plantation forest of hybrid Eucalyptus in Aek Nauli, Simalungun District, North Sumatera. Models were tested and assessed for statistical validity and accuracy in predicting biomass and carbon, based on determination coefficient $\left(R^{2}\right)$ and correlation coefficient ( $r)$, aggregative deviation percentage (AgD), and the average deviation percentage (AvD). The best general model to estimate the biomass of hybrid Eucalyptus was $Y=1351,09 x^{0,876} \cdot e^{(0,094 x)}$. Results showed that hybrid Eucalyptus had an average above-ground biomass in year 0 (the land without the eucalyptus trees) up to year 3 as large as 1.36, 11.56, 43.18, and 63.84 tha $\mathrm{a}^{-1}$. The carbon content of hybrid Eucalyptus were 0.61, 5.2, 19,43 t, and $28,73 \mathrm{tCha}^{-1}$ while the carbon sequestration potential were $2.23,19.08,71.31$, and $105.43 \mathrm{t} \mathrm{CO}_{2} \mathrm{ha}^{-1}$ respectively.
\end{abstract}

Keywords: biomass, carbon stock, model, hybrid Eucalyptus, plantation forest

*Correspondence author, email:sitilatifah164@yahoo.co.id, telp: +62-813-9613-2569

\section{Introduction}

Global warming, basically consitutes a phenomenon of increasing earth temperature which occurs globally from year to year. Global warming is caused by increasing emission of greenhouse gasses such as carbon dioxide $\left(\mathrm{CO}_{2}\right)$, methane $\left(\mathrm{CH}_{4}\right)$, dinitrooxide $\left(\mathrm{N}_{2} \mathrm{O}\right)$, and $(\mathrm{CFC})$. This causes solar energy being trapped within earth atmosphere (Cruz et al. 2007). This change in global climate would affect forestry and agricultural sector (Anderson et al. 2011).

In relation with forest ability to absorb carbon, emission trade or carbon trade constitutes a new paradigm in forestry sector and could become opportunity for Indonesia which is a developing country, to obtain foreign exchange from this sector. Global initiative, such as Kyoto Protocol has created new challenge to view forest from a different angle. Forest is not only stacks of wood which could generate foreign exchange, but also constitutes global commodity which possesses non wood potency.

One of the efforts to minimize impacts from climate change is stabilizing the $\mathrm{CO}_{2}$ concentration in atmosphere. This is related with forest ability to absorb $\mathrm{CO}_{2}$ from atmosphere, and then store it in forest stand in the form of organic matter or plant biomass. Therefore, potency of forest in carbon absorption could be estimated through calculation of plant biomass, because half of the biomass comprise carbon (IPCC 2001).

Eucalypt is one of the plant species which has potency in development of industrial plantation forest (Mindawati 2010), and has opportunity to produce carbon within rotation period (cutting cycle) which is considerably short (7-10 years) from growth process of the the planted trees (Aswandi 2007). Estimated volume of Eucalyptus urograndis stand at rotation 1 and rotation 2 at the ages of $5-5.5$ years could reach around $176-197 \mathrm{~m}^{3} \mathrm{ha}^{-1}$. Eucalyptus is one of the fast growing plant species which could be developed in many places (Bison et al. 2007). Eucalyptus spp., such as the species E. urophyllz, E. pellita, and $E$. grandis constitute the species which are developed as pulp industry raw materials, in large scale in PT. Toba Pulp Lestari with cutting cycle (rotation) of 7-8 years. Hybrid species of Eucalyptus, such as E. pellitagrandis (E.pellita $\times$ E. grandis) and E. urograndis (E. uropyhlla $\times E$. grandis) have been succesfully developed widely in HTI (Industrial Plantation Forest) in North Sumatra with better growth performance as compared to their parents (Latifah 2009). Considering the forest function as carbon sequestering medium, information on the amount of carbon which is stored by a forest territory (carbon stock) becomes important. 
Research on biomass and plant carbon of hybrid eucalypt is important to be conducted because this will be useful for plantation forest management plan, and constitutes one of the keys to support the success of HTI development in Indonesia in sustainable manner in the future. Sustainable forest would have potential of environmental service to sequester carbon in increasing amount and duration in accordance with the determined rotation time.

Efforts to quantify the amount of carbon which could be sequestered and stored ( $C$-stock) by forest is needed very much for utilizing forest as carbon sequestering medium through a framework of carbon trade. Research results in the form of techniques and method of carbon storage estimation could be socialized to forest managers. There are also acknowledgements from international world toward efforts being conducted by Indonesian people to mitigate and adapt with the global warming. Indonesia possesses large area of HTI of Eucalyptus with large potential of biomass storage. Research on the biomass estimation of HTI of Eucalyptus needs to be conducted to provide data for estimating environmental service of carbon sequestration of a forest territory, particularly the plantation forest of hybrid eucalypt.

\section{Methods}

Research was conducted in April-May 2011 in HTI of PT Toba Pulp Lestari in Aek Nauli sector, Medan, which is geographically situated between $02^{\circ} 40^{\prime} 00^{\prime \prime}-02^{\circ} 50^{\prime} 00^{\prime \prime}$ North Latitude and $98^{\circ} 50^{\prime} 00^{\prime \prime}-99^{\circ} 10^{\prime} 00^{\prime \prime}$ West Longitude, and Laboratory of Forest Inventory, Forestry Study Program, Faculty of Agriculture, University of North Sumatera. Research activities were focused on obtaining reliable model to estimate above ground biomass in hybrid eucalypt stand at $1-3$ years of age.

Equipments being used in this research were measurement tape, hypsometer, and chainsaw. Materials being used in this research were stems, branches, leaves, and shoots which were taken from stand which were 1-3 years old.

Measurement plot (PU) being used in this study had the size of $30 \times 20 \mathrm{~m}$ ( 6 PU for each age class) and distance between PU were $10 \times 10 \mathrm{~m}$ ( JICA 2002). Placement of PU was conducted by systematic sampling with random start. The collected data comprise diameter at breast height (dbh), branch free height, area size of crown section, and total tree height. Measurement of undergrowth vegetation was conducted at sub plots, measuring $2 \times 2 \mathrm{~m}$, within the PU.

Harvesting of biomass carbon stock is generally derived from the quantity of above ground biomass by assuming that $45 \%$ of the biomass value is composed of carbon (Onrizal 2004). Method which is most accurate is through destructive approach by cutting down trees and weighing all parts of the tree. Such destructive approach is frequently used to validate other method which tend to be less disturbing and requires low cost, such as carbon stock estimation by in situ non destructive and remote sensing measurement (Clark et al. 2001; Hua et al. 2007).

Selected sample trees ( 3 trees for each age class) were cut down and their diameter measured at points of $0,0.3,1.3$, $3.3,5.3,7.3$, and $9,3 \mathrm{~m}$ above ground surface, and afterwards there was separation of tree parts into stems, branches, and leaves. Weighing was conducted for all tree parts. In stem part, there were data collection on length and fresh weight per section, whereas in branches, leaves, and shoots there were data collection on fresh weight. Litters and undergrowth vegetation were collected and classified into particular parts, and their fresh weight were measured.

Characteristics of sample trees Wood test samples were in the form of cube measuring $2 \times 2 \times 2 \mathrm{~cm}$, comprising 3 replications for each lower end, middle and upper end of stem. All wood test samples were weighed for determining their fresh weight, and were subsequently dried in oven at temperature of $103^{\circ} \mathrm{C} \pm 2{ }^{\circ} \mathrm{C}$ for determining their dry weight. Percentage of water content (WC) was calculated with the following formula:

$\% W C=\frac{F W-O D W}{O D W} \times 100 \%$

note:

$\% W C=$ percentage of water content

$O D W=$ oven dry weight of test sample $(\mathrm{g})$

$F W \quad=$ fresh weight of test sample $(\mathrm{g})$

Plant tissues and litter were weighed as much as $\pm 100 \mathrm{~g}$ with 3 replications and dried in oven with temperature of \pm $80{ }^{\circ} \mathrm{C}$ until reaching constant weight (dry weight). Density of wood test samples need to be known to calculate biomass of stem parts through approach of wood density with the following formula (Haygreen \& Bowyer 1986):

$$
D=\frac{M}{V}
$$

note:

$D=$ density of wood test sample $\left(\mathrm{kg} \mathrm{m}^{-3}\right)$

$M=$ oven dry mass of wood test sample $(\mathrm{kg})$

$V=$ air dry volume of wood test sample $\left(\mathrm{m}^{3}\right)$

Biomass of stem and undergrowth vegetation Development of biomass model by using the approach of wood density is based on equations which have been studied by biomass expert researchers in the past. Biomass calculation of stem segments on the basis of water content data (Haygreen \& Bowyer 1986) is as follows:

$O D W=F W \times\left[1+\frac{(\% W C)}{100}\right]$

note:

$O D W=$ oven dry weight of test sample $(\mathrm{g})$

$F W \quad=$ fresh weight of segment of eucalypt tree $(\mathrm{g})$

$\% W C=$ percentage of water content

Biomass of undergrowth vegetation and litter was calculated with the following formula:

$D W_{\text {tot }}=\frac{\left(\frac{F W_{t o t}}{D W_{t s}}\right)}{\left(\frac{F W_{t s}}{\text { Sarea }}\right)}$ 
note:

Dwtot $=$ total dry weight $\left(\mathrm{kg} \mathrm{m}^{-2}\right)$

FWtot $=$ total fresh weight $(\mathrm{kg})$

$D W t s=$ dry weight of test sample $(\mathrm{g})$

FWts = fresh weight of test sample $(\mathrm{g})$

Sarea $=$ area size of sample $\left(\mathrm{m}^{2}\right)$

Forest biomass could be used to estimate carbon content within forest vegetation because $45 \%$ of the biomass is composed of carbon. Carbon content could be estimated with the following formula (Onrizal 2004):

$C=B \times 0.45$

note:

$C=$ amount of carbon stock $\left(\mathrm{tCha}^{-1}\right)$

$B=$ biomass $\left(\mathrm{tha}^{-1}\right)$

$0.45=$ carbon content

Carbon sequestration $\left(\mathrm{Co}_{2}\right)$ could be estimated with the following formula (Bismark et al. 2008):

Sequestion of $\mathrm{CO}_{2}=\frac{\mathrm{MrCO}_{2}}{\mathrm{ArC}}$

or sequestration of $\mathrm{CO}_{2}=3.67 \times$ carbon content

note:

$M r=$ molecule relative

$A r=$ atom relative

Reliability test of biomass model According to Kuswadi (2004) and Catahan (2008) reliability test of a model is conducted by utilizing criteria to determine the best model in allometric model estimation, which comprise consideration on the largest determination coefficient $\left(R^{2}\right)$ and correlation coefficient $(r)$, aggregative deviation percentage $(A g D)<$ $1 \%$, and average deviation percentage $(A v D)>-1 \%$ and $<$ $10 \%$. The quantity of those values are as follows:

$A g D=\left[\frac{\sum B a-\sum B e}{B e}\right] \times 100 \%$
$A v D=\frac{\left[\frac{B a-B e}{B e}\right]}{N} \times 100 \%$

note:

$B a=$ actual tree biomass

$B e=$ estimated tree biomass

$N=$ number of tree sample

Selection of model also considers the simplicity of model and their practicability to be used in the field (Catahan 2008).

\section{Results and Discussion}

Water content Laboratory results showed variation of water content (Figure 1). Descriptively, water content for each age class tended to decrease with increasing age. This was caused by phenomenon that the older the plant, the greater would be the wood constituent elements. Stems in young plants still had little wood element constituent, so that their water contents were greater. Stems in older tree have possessed maximum amount of wood element constituent, so that water content at older age become smaller (Haygreen \& Bowyer 1986). Research results by Pambudi (2011) showed the same trend, where the water content of Rhizhophora apiculata tended to decrease with increasing tree age.

Distribution of diameter and height of sample trees Data on age distribution and general condition of the research location were taken from map of tree distribution which was issued by PT Toba Pulp Lestari Tbk. Data collection of hybrid eucalypt plants were collected on plants of year 2008 up to year 2011 with random placement of measurement plots. Based on test result, it was obtained that correlation value between diameter and total height of hybrid eucalypt plants was 0.988 . Correlation in sample trees showed close relationship between the two parameters. On the basis of such relation, model being compiled to estimate tree

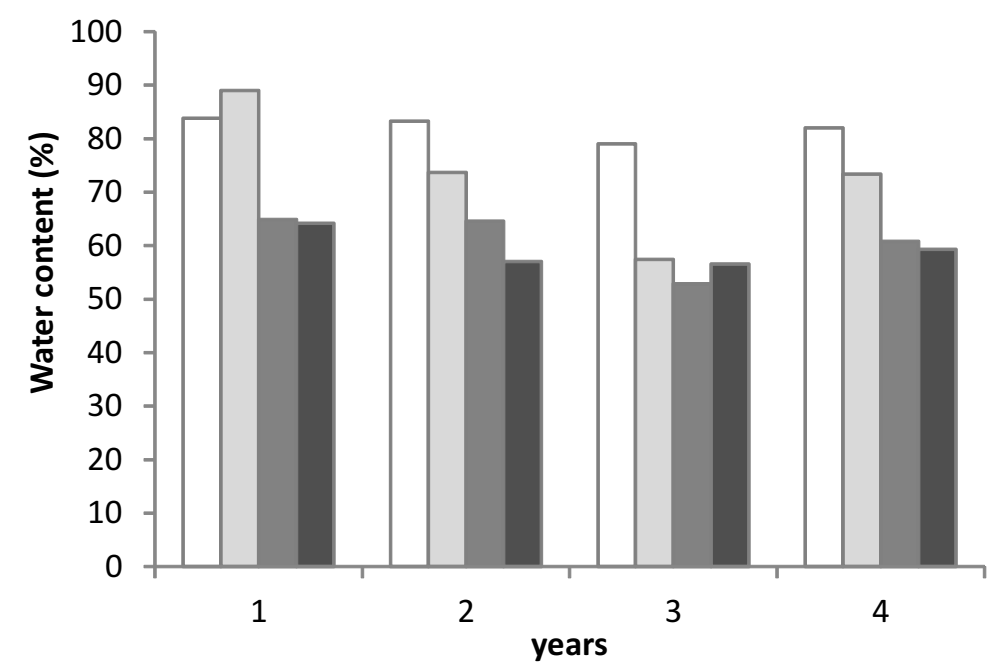

Figure 1 Water (moisture content) of hybrid eucalypt stand. Stem ( $\square$ ), leaves ( $\square$ ), branch ( $\square$ ), twig ( $\square$ ). 
biomass could use one of the variables. Independent variable is diameter or total height, whereas dependent variable is tree biomass.

According to Baker et al. (2002), choice of variable diameter at breast height ( $\mathrm{dbh}$ ) would improve the efficiency and reduce uncertainty of measurement result on the basis of equation which had been established, whereas choice of variable tree height tended to reduce measurement efficiency because variable tree height is more difficult to measure than that of diameter at breast height.

Models of biomass estimator Model of biomass estimator of hybrid eucalypt used data of stem dry weight, branch dry weight, twig dry weight, and leaf dry weight in the biomass measurement. On the basis of measurement of sample trees, there was construction of model which described the relationship between biomass and several variables. Several allometric models of biomass estimator were tried to obtain the best model for biomass estimation. Reliability test of the model was conducted to measure the model ability to estimate a group of new data which possessed relatively similar condition with condition of data which were used to establish the model.

In terms of model application, alometric equation is specific for a particular species and location, so that allometric equations could not be compared across different species and locations. However, in terms of composition of variables and forms of equation, various allometric equation could be compared to obtain the best model (Wenbo 2007). Basically a good model is that which is simple enough, easy to be analyzed and easy to be applied. Apart from those, models should have considerably high accuracy of estimation (Latifah 2000). In general, the tested allometric model were grouped into 2 categories, namely general and specific model. General model constitutes model which is used to estimate biomass by combining several age classes. In this research, general models were tested, and could be seen in Table 1.

General model for biomass estimation by using 1,2, and 3 variables could be seen in Table 1 . In general, the selected model for each variable being tested, had good performance. On the basis of statistical analysis, it was obtained that allometric model $Y=1,351.09 x^{0.876} \cdot \mathrm{e}^{(0.094 x)}$ had the best performance. This allometric model possessed $R^{2}$ value as large as $98,29 \%, \mathrm{r}$ as large as $0.9849, \mathrm{AgD}$ as large as $0,08 \%$, and AvD as large as $-0.28 \%$. Therefore, this model fulfilled the requirement as a reliable model. Catahan (2008) stated that a model is categorized as reliable if the aggregative deviation percentage $(\mathrm{AgD})<1 \%$ and $-1 \%<$ AvD $<10 \%$. Besides statistical consideration, according to Catahan (2008), the choice of best equation model should also consider the factor of practicability, efficiency, and ease in the collection of independent variable data in the equation.

Average deviation and aggregate deviation were used to measure the accuracy of a model. The smaller the values of $\mathrm{AgD}$ and AvD the more accurate would be the model. The value of $\mathrm{AgD}$ as large as $0.08 \%$ showed that the percentage of difference between value of estimation result and value of biomass measurement result of hybrid eucalypt was 0.08 . On the other hand, value of AvD as large as $-0.28 \%$ showed that average value of biomass estimation of hybrid eucalypt deviated as large as 0.28 from average value of their measurement result. Allometric model $Y=1351,09 x^{0.876}$. $\mathrm{e}^{(0.094 x)}$ had possessed good value, while its $\mathrm{AgD}$ and $\mathrm{AvD}$ were in conformity with the determined criteria.

Potency of biomass and carbon storage Biomass constitutes the amount of organic matter being produced by organism per unit area at a certain particular time. Biomass could be classified into 2 categories, namely above ground biomass and below ground biomass. This research was focused on above ground biomass estimation. Biomass was

Table 1 Testing of general allometric models of hybrid eucalypt stand

\begin{tabular}{|c|c|c|c|c|c|}
\hline $\begin{array}{c}\text { Number } \\
\text { of } \\
\text { variables }\end{array}$ & Model & $R(\%)$ & $R^{2}(\%)$ & $\operatorname{AgD}(\%)$ & $\operatorname{AvD}(\%)$ \\
\hline \multicolumn{6}{|c|}{ General model } \\
\hline \multirow{3}{*}{1} & $\#^{*} \quad \mathrm{Y}=1351,09 \times \times^{0,876} \cdot \mathrm{e}^{(0,094 \times)}$ & 98,49 & 98,29 & 0,08 & $-0,28$ \\
\hline & $Y=1483.5 x^{0,875}$ & 98,49 & 98,29 & 0,08 & $-0,28$ \\
\hline & $Y=1410.76 \times /(1-0,041 \times)$ & 96,48 & 96,27 & 0,16 & $-0,42$ \\
\hline \multirow{3}{*}{2} & $\begin{array}{l}* Y=-81065,015+1740,619 \log \left(\times_{1}\right)-5976,780 \log \left(\times_{1}\right)^{2}+4463,111 \\
\log \left(\times_{1}\right)^{3}+28819,559 \log \left(\times_{2}\right)-2447,331 \log \left(\times_{2}\right)^{2}\end{array}$ & 99,24 & 98,93 & 0,02 & $-0,35$ \\
\hline & $\begin{array}{l}Y=6705,353-1231,794 \times{ }_{1}+503,491 \times \times_{1}^{2}-14,433 \times{ }_{1}^{3}- \\
18,548 \times{ }_{2}+0,042 \times{ }_{2}^{2}+3,637.10^{-5} \times{ }_{2}{ }^{3}+9,99.10^{-9} \times_{2}{ }^{4}\end{array}$ & 99,24 & 98,71 & 0,02 & $-0,35$ \\
\hline & $\begin{array}{l}Y=2786,756+5739,094 \log \left(\times_{1}\right)-8660,742 \log \left(\times_{1}\right)^{2}+4948,473 \\
\log \left(\times_{1}\right)^{3}-1,554 \times_{2}-0,001 \times{ }_{2}^{2}\end{array}$ & 99,24 & 98,92 & 0,06 & $-0,38$ \\
\hline \multirow{2}{*}{3} & $* Y=\exp \left(0,255 \times{ }_{1}-3,167.10^{-4} \times_{2}+\times_{3}+7,751\right)$ & 97,98 & 97,55 & 0,24 & 0,92 \\
\hline & $Y=3502,018 \times_{1}+2,468 \times_{2}-2309,127 \times_{3}$ & 95,42 & 94,81 & 0,32 & 1,81 \\
\hline
\end{tabular}

Notes:

$*$ = The selected model for each category of number of variable.

\#* $=$ The selected general model 
Table 2 Carbon storage of hybrid eucalypt stand

\begin{tabular}{cccccr}
\hline Age (year) & $\begin{array}{c}\text { PU } \\
\left(\begin{array}{c}\text { measurement } \\
\text { plot })\end{array}\right.\end{array}$ & $\begin{array}{c}\text { Biomass } \\
\left(\mathrm{g} \mathrm{plot}^{-1}\right)\end{array}$ & $\begin{array}{c}\text { Carbon } \\
\left(\mathrm{g} \mathrm{plot}^{-1}\right)\end{array}$ & $\begin{array}{c}\text { Biomass } \\
\left(\mathrm{t} \mathrm{ha}^{-1}\right)\end{array}$ & $\begin{array}{r}\text { Carbon } \\
\left(\mathrm{t} \mathrm{ha}^{-1}\right)\end{array}$ \\
\hline 1 & 1 & $456,999.988$ & $205,649.995$ & 7.617 & 3.427 \\
& 2 & $477,020.623$ & $214,659.281$ & 7.950 & 3.578 \\
& 3 & $472,642.703$ & $212,689.216$ & 7.877 & 3.545 \\
\hline 2 & Average & $468,887.771$ & $210,999.497$ & 7.815 & 14.076 \\
& 1 & $1,876,861.310$ & $844,587.590$ & 31.281 & 14.629 \\
& 2 & $1,950,567.691$ & $877,755.461$ & 32.509 & 14.381 \\
\hline 3 & $1,917,430.304$ & $862,843.637$ & 31.957 & 14.362 \\
\hline & Average & $1,914,953.102$ & $861,728.896$ & 31.916 & 21.113 \\
& 1 & $2,815,023.105$ & $1,266,760.397$ & 46.917 & 21.828 \\
& 2 & $2,910,363.071$ & $1,309,663.382$ & 48.506 & 11.604 \\
\hline & 3 & $1,547,173.665$ & $696,228.149$ & 25.786 & 18.181 \\
\hline
\end{tabular}

Table 3 Potency of carbon absorption in hybrid eucalypt stand

\begin{tabular}{cccc}
\hline $\begin{array}{l}\text { Age } \\
\text { (year) }\end{array}$ & $\begin{array}{c}\text { PU } \\
\text { (measurement plot) }\end{array}$ & $\begin{array}{c}\text { Carbon } \\
\left(\mathrm{C} \mathrm{t} \mathrm{ha}^{-1}\right)\end{array}$ & $\begin{array}{c}\text { Absorption of } \mathrm{CO}_{2} \\
\left(\mathrm{t} \mathrm{CO}_{2} \mathrm{ha}^{-1}\right)\end{array}$ \\
\hline 1 & 1 & 3.427 & 12.577 \\
& 2 & 3.578 & 13.131 \\
& 3 & 3.545 & 13.010 \\
\hline 2 & Average & 3.517 & 12.907 \\
\hline 3 & 1 & 14.076 & 51.659 \\
& 2 & 14.629 & 53.688 \\
& 3 & 14.381 & 52.778 \\
\hline & Average & 14.362 & 52.708 \\
\hline & 1 & 21.113 & 77.485 \\
& 2 & 21.828 & 80.108 \\
& 3 & 11.604 & 42.587 \\
\hline
\end{tabular}

measured on the basis of dry weight because of prevailing variability of water content in each plant. Unit of biomass measurement was gram per $\mathrm{m}^{2}$ or $\mathrm{kg}$ per ha.

The general allometric model which had been selected was used to estimate carbon storage per tree by using data of stem diameter measured in the measurement plot. From results of calculation, using model $Y=1351,09 x^{0.876} \cdot \mathrm{e}^{0.876(0.094 x)}$ which constituted the best model by using plant diameter data from measurement results, eucalypt carbon storage were obtained and shown in Table 2. Estimation of stand biomass at various systems of land unit in Indonesia have been frequently conducted. Research results showed that biomass of hybrid eucalypt stand at ages of 1, 2, and 3 years were consecutively 7.8,31.9, and 40,4 ton $\mathrm{ha}^{-1}$. On the other hand, carbon potency at hybrid eucalypt stand at ages of 1,2 , and 3 years were consecutively $3.5,14.3$, and 18.2 ton ha $^{-1}$ (Table
2). Biomass and carbon potency of hybrid eucalypt stand tended to increase with increasing plant age. Research results by Baker et al. (2002), Pambudi (2011) and Andre et al. (2005) showed similar trend where plant biomass tended to increase together with increase in tree age.

Research results showed that potency of biomass and carbon of 3 years old hybrid eucalypt was 40.4 and 18.18 ton ha $^{-1}$ (Tabel 2) which were much higher as compared to biomass and carbon potency of acacia plant which was 29.53 and 18.04 ton $\mathrm{ha}^{-1}$ (Heriansyah 2005). Istomo (2002), in his research in swamp forest of Rokan Hilir district, Riau, showed that total biomass of that swamp forest was 329.18 ton $\mathrm{ha}^{-1}$, whereas Hairiah (2007) showed that natural forest possessed the highest amount of stored $\mathrm{C}$ (around $497 \mathrm{Mg} \mathrm{ha} \mathrm{ha}^{-1}$ ) as compared to other land use system. Disturbance which convert natural forest into secondary 
forest caused loss of around $250 \mathrm{Mg} \mathrm{C} \mathrm{ha}^{-1}$. The biggest loss of $\mathrm{C}$ above ground surface was due to vegetation loss.

Carbon sequestration Sequestration of $\mathrm{CO}_{2}$ carbon of hybrid eucalypt at ages of 1,2 and 3 years were consecutively 13, 52.7, and 66.7 ton $\mathrm{CO}_{2}$ ha $^{-1}$. In Table 3 , it could be seen that increase in plant age is linearly related with increase in carbon storage and sequestration of $\mathrm{CO}_{2}$ by the stand. This phenomenon was in agreement with that in Aswandi (2007) research which stated that with increasing plant age, the number of plant composition was also larger. Biomass and carbon in a particular area describe the ability of that area to fix $\mathrm{CO}_{2}$ from the atmosphere, and also describe the potential energy possessed by the area. The denser the vegetation of an area, the higher would be the ability to fix $\mathrm{CO}_{2}$ from the air, and the greater also would be the energy being stored in the area, and vice versa.

Forest absorb $\mathrm{CO}_{2}$ during photosynthesis process and store it as organic matter in plant biomass. Photosynthetic process occuring in older stand would run more smoothly, because chemical elements or components are more complete, so that plant production, namely growth of stems, leaves, twigs and roots become more abundant and rapid. Photosynthesis products are stored among others in the form of biomass which makes the vegetation grows larger and taller. The amount of organic material which is stored in forest biomass per unit of area and per unit of time constitute the main issue of forest productivity. Forest productivity describes the ability of forest to reduce $\mathrm{CO}_{2}$ emission in atmosphere through their physiological activities. Measurement of forest productivity in the context of this study is relevant with biomass measurement. Forest biomass provides important information to estimate biomass potency and absorption of $\mathrm{CO}_{2}$ at particular age which can be used to estimate forest productivity.
On the basis of Table 3, it could be seen that the amount of stand biomass was linearly related with carbon potency and carbon absorption by the stand. Biomass potential energy which is utilized properly can be beneficial for human life, while uncontrolled use of the biomass, such as for burning, will increase carbon emission to the air (one of the cause of greenhouse gas effect and global climate change). On the other hand, disposal of biomass to water bodies will pollute the water itself.

The amount of carbon content in forest stand is affected largely by the ability of vegetation in absorbing carbon from the environment through photosynthesis. Products of that photosynthesis process are accumulated in plant biomass, so that the total carbon of hybrid eucalypt stand is positively correlated with volume and weight of the biomass.

Potency of biomass and carbon of undergrowth vegetation and litter Undergrowth vegetation and litter constitute the medium for carbon storage, besides the forest stand. Sundarapandian (2009) explained that undergrowth vegetation constitutes non tree vegetation, such as grasses, herbs, bush and scrub, and liana which grow in the forest floor.

In relation with age classes, average biomass of undergrowth vegetation was as large as $1,35 \mathrm{tha}^{-1}$, carbon storage was $0.61 \mathrm{t} \mathrm{C} \mathrm{ha}^{-1}$, and absorption of $\mathrm{CO}_{2}$ was $2.23 \mathrm{t}$ $\mathrm{ha}^{-1}$. The amount of biomass, carbon storage, and absorption of $\mathrm{CO}_{2}$ increased progressively at the the age of 1 year, and were consecutively $3.32,1.49$, and $5.48 \mathrm{t} \mathrm{ha}^{-1}$. At the age of 2 years, the value of biomass, carbon, and absorption of $\mathrm{CO}_{2}$ were consecutively $3.12,1.41$, and $5.1612 \mathrm{tha}^{-1}$. On the other hand, at the age of 3 years, the value of biomass, carbon, and carbon absorption were consecutively 7.71, 3.47, and 12.73 ha $^{-1}$ (Table 4).

Analysis results which could be seen in Table 4

Table 4 Potency of biomass, carbon, and absorption of $\mathrm{CO}_{2}$ in undergrowth vegetation and litter in hybrid eucalypt stand

\begin{tabular}{ccccccc}
\hline & \multicolumn{2}{c}{$\begin{array}{c}\text { Biomass } \\
\left(\mathrm{t} \mathrm{ha}^{-1}\right)\end{array}$} & \multicolumn{2}{c}{$\begin{array}{c}\text { Carbon } \\
\left(\mathrm{t} \mathrm{ha}^{-1}\right)\end{array}$} & & \multicolumn{2}{c}{$\begin{array}{c}\text { Absorption of } \mathrm{CO}_{2} \\
\text { Age (year ) }\end{array}$} & $\begin{array}{c}\text { undergrowth } \\
\text { vegetation }\end{array}$ & Litter & $\begin{array}{c}\text { undergrowth } \\
\text { vegetation }\end{array}$ & Litter & $\begin{array}{c}\text { undergrowth } \\
\text { vegetation }\end{array}$ & Litter \\
\hline 0 & 1.353 & 0.008 & 0.609 & 0.004 & 2.234 & 0.014 \\
1 & 3.317 & 0.422 & 1.493 & 0.190 & 5.478 & 0.697 \\
2 & 3.123 & 8.142 & 1.405 & 3.664 & 5.158 & 13.447 \\
3 & 7.709 & 15.728 & 3.469 & 7.078 & 12.731 & 25.975 \\
\hline
\end{tabular}

Table 5 Biomass, potency, and carbon absorption in hybrid eucalypt stand

\begin{tabular}{cccc}
\hline Age (year) & $\begin{array}{c}\text { Biomass } \\
\left(\mathrm{t} \mathrm{ha}^{-1}\right)\end{array}$ & $\begin{array}{c}\text { Carbon } \\
\left(\mathrm{t} \mathrm{ha}^{-1}\right)\end{array}$ & $\begin{array}{c}\text { Absorption of } \mathrm{CO}_{2} \\
\left(\mathrm{t} \mathrm{ha}^{-1}\right)\end{array}$ \\
\hline 0 & 1.362 & 0.613 & 2.248 \\
1 & 11.555 & 5.199 & 19.081 \\
2 & 43.181 & 19.431 & 71.313 \\
3 & 63.841 & 28.728 & 105.432 \\
\hline
\end{tabular}


showed that the highest average of undergrowth vegetation occured at the age of 3 years, namely $7.71 \mathrm{t} \mathrm{ha}^{-1}$ and that of the lowest was at the age of 0 year, namely $1.35 \mathrm{t} \mathrm{ha}^{-1}$. This was due to the phenomenon that undergrowth vegetation at 3 years old eucalypt stand was greater as compared to eucalypt stand at the age of 0 year (there had been no any eucalypt stand).

Litters are dead plant tissues which are either not yet decomposed or slightly decomposed. In relation with age classes, biomass in litter also varied (Table 4). Average biomass, carbon, and $\mathrm{CO}_{2}$ absorption of litter under eucalypt stand were consecutively $0.008,0.004$, and $0.01 \mathrm{t} \mathrm{ha}^{-1}$. Average biomass, carbon, and carbon absorption of litter at 1 year old stand were consecutively $0.42,0.19$, and $0.69 \mathrm{t} \mathrm{ha}^{-1}$. At 2 years old eucalypt stand, average biomass, carbon and carbon absorption of litter were consecutively 8.14, 3.67 , and $13.45 \mathrm{t} \mathrm{ha}^{-1}$. On the other hand, at 3 years old eucalypt stand, average biomass, carbon, and carbon absorption of litter were consecutively 15.73, 7.08, and $25.97 \mathrm{t} \mathrm{ha}^{-1}$. In general, it could be suggested that with the increasing age of the stand, the potency of biomass, carbon, and carbon absorption of the litter would become higher. This phenomenon could be explained because the ability of leaves, twig, branch and stem to regenerate, would become greater. The older the age of the stand, the greater would be the need for the trees to regenerate and therefore the greater would be the shedding of tree parts, such as leaves, twig, branches, and stem. Therefore, the amount of litter would become greater with increasing age of the stand.

Potency of biomass and carbon above ground surface Potency of carbon storage above ground surface could be estimated from the amount of biomass of the upper part of the hybrid eucalypt stand. Such biomass constituted the summation of biomass of undergrowth vegetation and litter in the hybrid eucalypt stand (Table 2, Table 3, and Table 4). Table 5 shows the amount of the carbon storage. Biomass at 0 year old constituted the summation of litter and undergrowth biomass on land without hybrid eucalypt stand (because 0 year old plantation implied that there was no hybrid eucalypt plants).

Biomass, carbon storage, and absorption of $\mathrm{CO}_{2}$ above ground surface of hybrid eucalypt stand exhibited increase with increasing age of the plants (Table5). Physical properties or environmental condition constituted the important factor for supporting plant growth and development. Accumulation of biomass in tropical region is greater than that in temperate area, because photosynthesis rate in tropical region is greater (Indriyanto 2006). According to Mulyana et al. (2011) variable of environmental condition, namely temperature, air humidity, soil temperature, and litter thickness showed differences among various types of land cover. Existence of large difference of biomass in forest stand was due to difference in soil fertility, site, and the species of eucalyptus (Wei 2000). This could be explained by the phenomenon that acceptance of $\mathrm{CO}_{2}$ is greater in site with lower elevation $\left(\mathrm{CO}_{2}\right.$ is heavier than air and tends to go down during low turbulence). Forest land possesses more fertile site, and this will affect the level of photosynthesis in producing carbohydrate in stem, so that forest stand biomass will increase (Medhurst et al. 2001). Besides that, soil and water management constitute the important factor in affecting the success of plant growth, and this will afterwards affect the volume and weight of plant biomass (Datta 2007). Research result by Hopmans et al. (2005) showed that controlled land burning could substantially increase the content of coarse charcoal in soil, and hence will also increase the total carbon content. Also, the management of harvesting would affect forest biomass and soil carbon content in eucalypt forest stand. Soil carbon content ranges between 2-9\%, and was lower than result of simulation of harvesting of the whole tree. On the other hand, soil carbon revealed from harvesting simulation was greater (in the range between $5-17 \%$ ) than that in land where there was no harvesting activity (Ranatunga et al. 2008).

According to Latifah (2009), hybrid eucalypt possessed better growth than that of species E. grandis, E. pellita, and E. uropyhla so that biomass of hybrid eucalypt tended to be greater as compared with that of other species of Eucaliptus. Research result by Yue et al. (2007) also showed that height growth of E. globulus was smaller than that of hybrid eucalypt.

Research result by Baker et al. (2002) showed that above ground biomass of 45 months old (almost 4 years) E. urophylla stand with stand density of 2.124 stems ha $^{-1}$ was as large as $58.3 \mathrm{t} \mathrm{ha}^{-1}$, that of 21 months old was $25.5 \mathrm{t} \mathrm{ha}^{-1}$, whereas that of 33 months old E. teriticornis was $40.1 \mathrm{t} \mathrm{ha}^{-1}$ which were relatively lower than biomass potency of hybrid eucalypt revealed by this research. Other research results, as comparison, showed that douglas-fir (Pseudotsugamenziesii (Mirb.) Franco) in Oregon forest of USA contained large amount of organic matter $\left(222 \mathrm{Mg} \mathrm{ha}^{-1}\right)$ and $\mathrm{C}\left(100 \mathrm{Mg} \mathrm{ha}^{-1}\right)$ ( Means et al. 1992).

Widhiastuti (2009) reported that carbon potency stored in trees, poles, and saplings which were studied non destructively (biomass in seedlings and necromass was not yet measured) in forest territory of TWA Sicikeh-cikeh was as large as $113.96 \mathrm{t} \mathrm{ha}^{-1}$. Amount of carbon stored in each ecosystem varied. This was due to difference in diversity and complexity of components which compose the ecosystem. Research by Aide ( 2001) showed that above ground biomass and species richness of secondary forest site were nearly similar with those of old forest growth $(>80$ years) after undergoing succession of around 40 years. Complexity of ecosystem would affect the rate of carbon cycle which pass through each of its component (Indriyanto 2006).

According to Suhendang (2002), one of the environmental services which could be produced from forest is the very big role of the forest in ecological cycle (such as controlling the cycles of carbon, oxygen, nutrient element, water and world climate cycle). Countries which are able to absorb the excess of green house gas emission produced by other countries which exceed their quality standard, would have the right to get incentives for this service. Absorption of excessive emission of green house gases emission by forest vegetation will occur only if there are tree growths in new forest or in young forest. The amount of total emission of green house gases all over the world which 
exceed the allowable emission threshold constitute a world demand in international market. This total excessive carbon emission is being traded, and this is known with the term carbon trade. In the carbon trade, actually the item being traded is forest services in absorbing the excessive (as compared to the allowable emission) carbon emission in the world.

One of the factors which could reduce the accumulation $\mathrm{CO}_{2}$ in the atmosphere is absorption by vegetation. Industrial plantation forest, besides its ability to produce harvested timber in the end of its production cycle, can also act as air cleaner by utilizing $\mathrm{CO}_{2}$ in the atmosphere in photosynthesis process. Plantation forest of hybrid eucalypt could provide very relevant contribution in mitigating green house gases in certain period of time.

\section{Conclusion}

The potency of biomass, carbon, and carbon absorption above ground surface in industrial plantation forest of hybrid eucalypt increased in line with increasing plant age. Indonesia has great potential to become a country which absorb carbon emission due to its possession of large areas of tropical forest. Even, such potential could be increased by efforts of planting and rehabilitating forests which are heavily damaged and widely distributed, including the efforts of HTI program. At present, Indonesia should be able to look at its forest potential through different paradigm which implies that forest is not identical with wood anymore. Forests could provide services in other forms, namely playing a great role in protecting the earth atmosphere through absorption of carbon emission.

\section{Acknowledgements}

This research was partly funded by program of Competitive Grant of DIKTI (Directorate of Higher Education, Indonesia), year 2011. Gratitude is also extended to PT. Toba Pulp Lestari which gave permission to conduct this research in its area.

\section{References}

Aide TM, Zimmerman JK, Pascarella JB, Rivera L. 2000. Forest regeneration in a chronosequence of tropical abandoned pastures: implications for restoration ecology. Restoration Ecology 8(4):328-338. http://dx.doi.org/10.1046/j.1526-100x.2000.80048.x.

Andre LS et al. 2005. Age related equations for above-dan below ground biomass of a Eucalyptus hibrida in Congo. Forest Ecology and Management 105(1-3) :199-214.

Anderson P, Santoso I, Steni B, Mahaningtyas A, Mansur E, Ahmad M, Elson D. 2011. Tenure, governance, and climate change. Tropical Forest 20(4):17-18.

Aruan ALP. 2000. The Future Role of Plantation Forests and Forest-Based Industry. http://www.fao.org/ Docrep/Article/Wfc/Xii/0142-A1.htm [ 23 Juli 2008].

Aswandi, 2007. Model Pendugaan Biomassa di Atas Tanah Eucalyptus Grandis Pada Hutan Tanaman PT. Toba Pulp
Lestari Sektor Aek Nauli Simalungun Sumatera Utara. In : Proceeding of Seminar Sehari Peran Penelitian dan Pengembangan Pada Pembangunan Kehutanan di Sumatera Utara; Medan 28 Desember 2010. Medan: Balai Penelitian Kehutanan Aek Nauli. pp169-178

Baker T, Morris J, Duncan M, Ningnan Z, Zengjiang Y, Zhihong H, Guowei C. 2002. Tree and stand growth and biomass relationships for Eucalyptus urophylla and E. 12ABL on the Leizhou Peninsula, Guangdong Province, China. New Forest (2011) 41: 95-112. http://dx.doi.org/10.1007/s11056-010-9213-0.

Bison O, Ramalho M, Rezende GDSP, Aguiar AM, Rezende MDV. 2007. Combining ability of elite clones of Eucalyptus grandis and Eucalyptus urophylla with Eucalyptus globules. Genetics and Moleculer biology 30(2):417-422. http://dx.doi.org/10.1590/S141547572007000300019.

Bismark M, Heriyanto NM, Sofian I. 2008. Biomassa dan kandungan karbon pada hutan produksi di cagar biosfer Pulau Siberut, Sumatera Barat. Jurnal Penelitian Hutan dan Konservasi Alam. 5(5):397-407.

Catahan L. 2008. Applied Regression and Correlation Analysis. Statistic 151 Course. Philippines: University of the Philippines Los Banos Press.

Clark DA, Brown S, Kiclighter DW, Chamber JQ, Thomlinson JR, Ni J. 2001. Net primary production in tropical forest: an evaluation and synthesis of existing field data. Ecological Application 11(2):371-384. http://dx.doi.org/10.1890/1051-0761.

Cruz RV, Harasawa H, Lal M, Wu S, Anokhin Y, Punsalmaa B, Honda Y, Jafari M, Li C, Huu Ninh N. 2007. Climate Change 2007. In: Parry ML, Canziani OF, Palutikof JP, van der Linden PJ, Hanson CE, editors. Impacts, Adaptation and Vulnerability. Contribution of Working Group II to the Fourth Assessment Report of the Intergovernmental Panel on Climate Change. Cambridge: Cambridge University Press.

Datta M, Singh NP. 2007. Growth characteristic of multipurpose tree species, crop productivity and soil properties in agroforestry system under subtropical humid climate in India. Journal of Forest Research 18(4):261-270. $\quad$ http://dx.doi.org/10.1007/s11676007-0053-5.

Hairiah K, Rahayu S. 2007. Pengukuran Karbon Tersimpan di Bebagai Macam Penggunaan Lahan. Bogor: World Agroforestry Center-ICRAF.

Haygreen SG, Bowyer JL. 1986. Hasil Hutan dan Ilmu Kayu (Suatu Pengantar). Yogyakarta: Universitas Gadjah Mada Press.

Heriansyah I. 2005. Potensi hutan tanaman industri dalam mensequester karbon (studi kasus di hutan tanaman 
akasia dan pinus). http:io.ppijepang.org.[16 Januari 2012].

Hopmans P, Bauhus J, Khanna P, Weston C. 2005. Carbon and nitrogen in forest soils: potential indicators for sustainable management of eucalypt forests in southeastern Australia. Forest Ecology and Management $220(1-3): 75-87$. http://dx.doi.org/10.1016/j.foreco.2005.08.006.

Hua LZ, Morris J, He XB, Jiang XD. 2007. Predicting eucalyptus production in Southern China using the 3-PG model. Journal of Tropical Forest Science 19(3):116127.

Indriyanto. 2006. Ekologi Hutan. Jakarta: Bumi Aksara Press.

[IPCC] Intergovernmental Panel on Climate Change. 2001. Climate Change 2001: Impacts, Adaptation, and Vulnerability, Summary for Policy Makers. Working Group 23rd Assessment Report. http://www.usgcrp. gov/ipcc/html/specrep.html [28 Agustus 2010].

Istomo. 2002. Kandungan $\mathrm{C}$ dan $\mathrm{Ca}$ serta penyebaran pada tanah dan tumbuhan hutan rawa gambut Studi kasus di Kabupaten Rokan Hilar Riau [dissertation]. Bogor. Bogor Agricultural University.

Kuswadi, Mutiara E. 2004. Statistic Berbasis Computer untuk Orang-Orang Nonstatistik. Jakarta: PT Elex Media Komputindo.

Latifah S. 2000. Keragaan pertumbuhan Acacia mangium Willd pada lahan bekas tambang timah (studi kasus di areal kerja PT Timah Tbk) [thesis]. Bogor: Graduate School, Bogor Agricultural University.

Latifah S. 2009. Growth and yield models for eucalyptus species using geospatial technology in Aek Nauli, North Sumatra Province, Indonesia [dissertation]. Philippines: University of the Philippines Los Baños.

Means JE, MacMillan PC, Cromack K. 1992. Biomass and nutrient content of douglas-fir logs and other detrital pools in an old-growth forest, Oregon, USA. Canadian Journal of Forest Research. 22(10):1536-1546. http://dx.doi.org/10.1139/x92-204.

Medhurst JL, Beadle CL, Neilsen WA. 2001. Early-age and later-age thinning affects growth, dominance, and intraspecific competition in Eucalyptus nitens plantations. Canadian Journal of Forestry Research 31(2):187-196. http://dx.doi.org/10.1139/x11-135.

Mulyana D, Budi SW, Wasis B, Wulandari AS. 2011. Micro environmental change in various form land cover revegetation. Jurnal Manajemen Hutan Tropika 17(1):24-28

Mindawati N, Andry I, Mansur I, Rusdiana O. 2010. Kajian pertumbuhan tegakan hybrid $E$. urograndis di Sumatera Utara. Jurnal Penelitian Hutan Tanaman 7(1): 39-50

Onrizal. 2004. Model penduga biomassa dan karbon tegakan hutan kerangas di Taman Nasional Danau Sentarum, Kalimantan Barat [thesis]. Bogor: Graduate School, Bogor Agricultural University.

Pambudi GP. 2011. Pendugaan biomassa beberapa kelas umur tanaman Rhizhophora apiculata pada areal PT. Bina Ovivipari Semesta, Kabupaten Kubu Raya, Kalimanatan Barat. http://repository.ipb.ac.id [19 Februari 2012].

Ranatunga K, Keenan RJ, Wullschleger SD, Post WM, Tharp ML. 2008. Effect of harvest management practices on forest biomass and soil carbon in eucalypt forest in New South Wales, Australia: simulations with the forest succesion model LINGKAGES. Forest Ecology and Management 255(7):2407-2415.

Suhendang E. 2002. Pengantar Ilmu Kehutanan. Bogor: Yayasan Penerbit Fakultas Kehutanan IPB.

Sundarapandian SM, Swammy PS. 2009. Forest ecosystem structure and composition along and altitudinal gradient the Wastern Ghats, Shout India. Journal of Tropical Forest Science 12(1):104-123.

Widhiastuti R. 2009. Keanekaragaman vegetasi dan potensi karbon tersimpan di hutan taman wisata alam SicikehCikeh untuk pelestarian lingkungan. In: Proceeding Simposium Nasional Penelitian Perubahan Iklim Indonesia; Medan, 22 Agustus 2011. pp119-129.

Wenbo C, Xiaofan Z. 2007. Estimation of forest parameters based on TM imagery and statistical analysis. Journal of Forest Research 18(3):241-244.

Wei X, Nuno MGB. 2000. Genetic gains and levels of relatedness from best linier unbiased prediction of Eucalyptus europhylla for pulp production in Southeastern China. Canadian Journal of Forestry Research 30(10):1601-1607. http://dx.doi.org/10. 1139/cjfr-30-10-1601.

Yue W, Valerie M, Baker, Thomas G. 2007. Modeling and prediction of dominant height and site index of Eucalyptus globulus plantations using a nonlinear mixed-effects model approach. Canadian Journal of Forest Research 37(8):12-14. 